\title{
JURNALBASICEDU
}

Volume 5 Nomor 6 Tahun 2021 Halaman 5087 - 5099

Research \&Learningin Elementary Education

https://jbasic.org/index.php/basicedu

\section{Pengaruh Budaya Literasi terhadap Hasil Belajar IPA di Sekolah Dasar}

\author{
Frita Dwi Lestari $^{1 凶}$, Muslimin Ibrahim ${ }^{2}$, Syamsul Ghufron ${ }^{3}$, Pance Mariati ${ }^{4}$ \\ Pendidikan Guru Sekolah Dasar, Universitas Nahdlatul Ulama Surabaya, Indonesia ${ }^{1,2,3,4}$

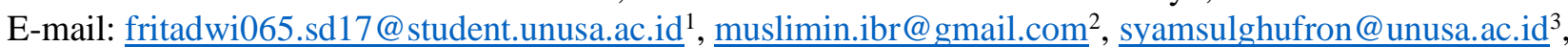 \\ pance_mariati@unusa.ac.id ${ }^{4}$
}

\begin{abstract}
Abstrak
Kurangnya minat siswa dalam membaca, memicu terjadinya degradasi wawasan dan ilmu pengetahuan. Tujuan penelitian ini, guna mengetahui pengaruh, keterlaksanaan dan respon siswa terkait pembelajaran yang mengintegrasikan budaya literasi pada pembelajaran IPA kelas IV Sekolah Dasar. Sasaran penelitian ini adalah seluruh siswa kelas IV dengan jumlah siswa sebanyak 12 siswa untuk kelas eksperimen dan 12 siswa untuk kelas kontrol di SDN Wonokusumo VI Tahun Ajaran 2021/2022. Penelitian menggunakan rancangan pretest-postest control group. Kelompok eksperimen dikenakan perlakukan budaya literasi yaitu berupa pembiasaan membaca 15 menit sebelum pembelajaran dilaksanakan. Setelah menganalisis data, penulis menemukan bahwa keterlaksaan pembelajaran budaya literasi $100 \%$ terlaksana sesuai dengan RPP yang sudah dirancang oleh peneliti. Selain itu, penerapan budaya literasi mempunyai pengaruh terhadap hasil belajar siswa kelas IV pada mata pelajaran IPA. Hal ini dibuktikan dengan perolehan nilai pada $t_{\text {hitung }}$ yaitu 2,426 lebih besar dari nilai tabel yaitu 2,075 atas dasar signifikan 0,05 diambil dari selisih nilai hasil belajar posttest dan pretest kelas eksperimen dan kontrol. Sehingga, dapat disimpulkan bahwa penerapan budaya literasi mempunyai pengaruh terhadap hasil belajar siswa kelas IV pada mata pelajaran IPA dan mendapatkan respon positif dari guru.
\end{abstract}

Kata Kunci: Pengaruh, Budaya literasi, Siswa

\begin{abstract}
The lack of student interest in reading triggers the degradation of insight and knowledge. The purpose of this study was to determine the effect, implementation and response of students related to learning that integrates literacy culture in science learning for grade IV Elementary School. The targets of this study were all fourth grade students with a total of 12 students for the experimental class and 12 students for the control class at SDN Wonokusumo VI Academic Year 2021/2022. The study used a pretest-posttest control group design. The experimental group was treated with literacy culture in the form of habituation to read 15 minutes before learning was carried out. After analyzing the data, the authors found that the implementation of 100\% literacy culture learning was carried out in accordance with the lesson plans that had been designed by the researchers. In addition, the application of literacy culture has an influence on the learning outcomes of fourth grade students in science subjects. This is evidenced by the acquisition of a value on tcount which is 2,426 which is greater than the value of ttable, which is 2,075 on the basis of a significant 0.05 taken from the difference in the value of the posttest and pretest learning outcomes of the experimental and control classes. So, it can be concluded that the application of literacy culture has an influence on the learning outcomes of fourth grade students in science subjects and gets a positive response from the teacher.
\end{abstract}

Keywords: Influence, Literacy Culture, Students

Copyright (c) 2021 Frita Dwi Lestari, Muslimin Ibrahim, Syamsul Ghufron, Pance Mariati

$\triangle$ Corresponding author :

Email : fritadwi065.sd17@student.unusa.ac.id

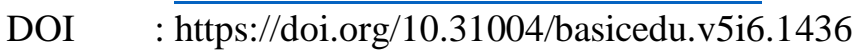

ISSN 2580-3735 (Media Cetak)

ISSN 2580-1147 (Media Online) 
5088 Pengaruh Budaya Literasi terhadap Hasil Belajar IPA di Sekolah Dasar - Frita Dwi Lestari, Muslimin Ibrahim, Syamsul Ghufron, Pance Mariati

DOI: https://doi.org/10.31004/basicedu.v5i6.1436

\section{PENDAHULUAN}

Membaca merupakan jendela ilmu karena dengan banyak membaca kita bisa menambah banyak wawasan dan ilmu pengetahuan. Sebagaimana yang kita ketahui, proses belajar untuk mendapatkan ilmu pengetahuan itu sendiri adalah melalui proses sains khususnya membaca. Karena sekitar 80-90\% ilmu pengetahuan berasal dari membaca. Kebiasaan membaca merupakan sesuatu yang penting dan fundamental yang harus dikembangkan sejak dini dalam rangka untuk meningkatkan kualitas penyelenggaraan pendidikan (Aswat \& Nurmaya G, 2019). Menurut Subakti, 2019 (dalam Subakti et al., 2021) ilmu pengetahuan dapat meningkat apabila dilakukan melalui banyak membaca buku-buku dengan latihan secara terus-menerus dan berkelanjutan (Subakti et al., 2021).

Menurut Tilaar (dalam Widiyono \& Nurhayati, n.d.), membaca merupakan proses membagikan makna kepada dunia (Widiyono \& Nurhayati, n.d.). Sayangnya, minat baca di negara ini masih bisa dikatakan sangat rendah. Pada tahun 2012 UNESCO mengeluarkan indeks minat baca di Indonesia dengan hasil yang dicapai sebesar 0.001. yang artinya, dari 1000 orang hanya terdapat 1 orang yang mempunyai minat membaca. Pada umumnya, penduduk Indonesia membaca buku baru 0-1 buku di setiap tahun (Lawalata \& Sholeh, 2019).

Hasil dari survei tersebut harusnya sudah menjadi tugas bagi kita sekalian khususnya pemerintah Indonesia untuk melakukan sebuah upaya agar bisa meningkatkan minat baca masyarakat Indonesia. Salah satu langkah yang sangat memastikan keberhasilan proses belajar mengajar adalah membaca. Pada tahun 2015 melalui Peraturan Menteri Pendidikan dan Kebudayaan Nomor 23 tahun 2015 menyusun strategi yang diberi nama Gerakan Literasi Sekolah. Kegiatan budaya literasi di sekolah diharapkan mampu menumbuhkan minat baca siswa agar siswa bisa menambah wawasan mereka dengan banyak membaca. Dengan demikian, gerakan budaya literasi ini juga diharapkan mampu memberikan hasil belajar yang bagus pula, karena wujud keberhasilan dari pembelajaran di sekolah bisa dilihat dari prestasi siswa. Prestasi belajar siswa itu sendiri merupakan hasil usaha yang dicapai siswa selama sepanjang aktivitas belajar di sekolah yang biasanya berupa nilai atau angka. Menurut Kamardana et al., 2021, program literasi dilaksanakan untuk mendorong siswa agar senantiasa haus akan ilmu pengetahuan, menjadikan mereka senang membaca dan akhirnya siswa memiliki wawasan yang lebih luas dan mendapatkan informasi baru (Kamardana et al., 2021).

Menurut, Harahap Hamjah Mukti (dalam Safitri \& Dafit, 2021) menjelaskan bahwa ada 3 ruang lingkup dalam GLS, yaitu (a) Lingkungan fisik yang ada disekolah contohnya seperti sarana prasarana literasi. (b) Lingkungan sosial misalnya dukungan dan partisipasi aktif dari seluruh warga sekolah, (c) Lingkungan akademik yaitu program litreasi yang dapat menumbuhkan minat baca dan menunjang kegiatan pembelajaran siswa disekolah (Safitri \& Dafit, 2021).

Kata budaya berasal dari bahasa sansekerta yaitu buddhayah yang merupakan bentuk jamak dari kata Buddi (budi atau akal) diartikan sebagai segala sesuatu yang berkaitan dengan akal dan budi manusia. Sedangkan dalam bahasa Inggris kebudayaan disebut dengan culture, yang berasal dari bahasa latin Colore yang diartikan sebagai mengolah atau mengerjakan. Dalam bahasa Indonesia kata Culture biasanya juga diterjemahkan sebagai "kultur" (Amiyah \& Subiyantoro, 2020).

Menurut Koentjaraningrat (dalam Devianty, 2017), kebudayaan merupakan bentuk sempurna yang terdapat di dalam benak manusia yang dapat berbentuk gagasan, ide, norma, kepercayaan dan lain sebagainya, namun bersifat abstrak dan tak dapat diraba. Menurut Taylor (dalam Devianty, 2017), kebudayaan merupakan lingkungan totalitas yang meliputi pengetahuan, keyakinan, kesenian, hukum, moral, kebiasaan, kecakapan yang diperoleh oleh manusia selaku anggota masyarakat. Menurut Lebra (dalam Devianty, 2017), kebudayaan adalah serangkaian simbol-simbol abstrak, universal, ataupun ideasional serta perilaku merupakan serangkaian gerak organisme yang bertenaga, bertabiat special serta dapat diamati. Dalam hal ini, perilaku merupakan perwujudan dari budaya atau kebudayaan yang memberi makna bagi manusia tersebut (Devianty, 2017). 
5089 Pengaruh Budaya Literasi terhadap Hasil Belajar IPA di Sekolah Dasar - Frita Dwi Lestari, Muslimin Ibrahim, Syamsul Ghufron, Pance Mariati

DOI: https://doi.org/10.31004/basicedu.v5i6.1436

Dari beberapa teori yang sudah dikemukakan oleh beberapa tokoh di atas, dapat disimpulkan bahwa kebudayaan adalah sesuatu yang hendak menjadi pengaruh pada tingkatan pengetahuan, serta meliputi sistem ide, atau gagasan yang terdapat di dalam fikiran manusia, sehingga dalam kehidupan sehari-hari kebudayaan itu bersifat abstrak.

Sedangkan untuk perwujudan dari budaya itu sendiri merupakan benda-benda yang diciptakan oleh manusia sebagai makhluk yang berbudaya, berupa perilaku, serta benda-benda nyata. Selaku contoh pola perilaku, peralatan hidup, bahasa, organisasi sosial, seni, religi, dan lain sebagainya. Dimana seluruhnya secara totalitas ini ditunjukkan untuk membantu manusia dalam melangsungkan kehidupan dalam bermasyarakat.

Pengertian Literasi menurut UNESCO (dalam Purwati, 2017) adalah wujud dari keterampilan yang secara nyata, yang secara spesifik adalah keteampilan kognitif dari membaca serta menulis, yang terlepas dari konteks di mana keterampilan itu diperoleh dari siapa serta cara memperolehnya. Beberapa hal yang dapat mempengaruhi seseorang tentang makna literasi itu sendiri adalah penelitian akademik, institusi, konteks nasional, nilai-nilai budaya, dan juga pengalaman (Purwati, 2017).

Literasi diartikan sebagai melek huruf, kemampuan membaca dan menulis, kemelekwacanaan atau kecakapan dalam membaca dan menulis. Pengertian literasi berdasarkan konteks pengunaannya merupakan integrase keterampilan menulis, membaca, dan berfikir kritis (Purwati, 2017).

Gee dalam Au (dalam Chairunnisa, 2018) yang mengartikan literasi dari sudut pandang kewacanaan menyatakan bahwa literasi adalh "mastery of, or fluent control over, a secondary discourse". Gee menjelaskan bahwa literasi adalah suatu keterampilan dari seseorang melalui kegiatan berfikir, membaca, menulis, dan berbicara (Chairunnisa, 2018).

Berdasarkan pendapat para ahli di atas, dapat disimpulkan bahwa literasi merupakan proses pembelajaran yang dilakukan secara komprehensif untuk mengidentifikasi, memahami informasi, berkomunikasi, dan menghitung menggunakan bahan cetak dan tertulis dengan berbagai konteks

Menurut Riley (dalam Dafit et al., 2020) literasi merupakan dasar keberhasilan dalam pembelajaran. Hubungan antara keberhasilan pembelajaran dengan tingkat melek huruf terjadi melalui kurikulum dan proses pembelajaran yang terjadi di sekolah (Dafit et al., 2020).

Menurut Suyono (dalam Gogahu \& Prasetyo, 2020) literasi dapat digunakan sebagai dasar pengembangan pembelajaran efektif di sekolah yang dapat membuat siswa terampil dalam mencari dan mengolah informasi yang dibutuhkan dalam kehidupan berbasis ilmu pengetahuan pada abad ke-21 (Gogahu \& Prasetyo, 2020).

Berdasarkan hasil dari teori tentang budaya dan literasi di atas, maka dapat dikatakan bahwa budaya literasi merupakan suatu aktivitas yang dilakukan untuk mendukung terwujudnya pembelajaran yang efektif dan efesien. Selain itu, budaya literasi juda dapat diartikan sebagai alat bantu dalam proses pembelajaran untuk menambah wawasan siswa, pembendaharaan kata, melatih menulis, serta menumbuhkan minat baca pada anak sejak dini.

Menurut Wiedarti \& Laksono (dalam Anggraeni, 2019) tahapan dalam budaya literasi adalah sebagai berikut:

a. Tahap ke-1: Pembiasaan

Melaksanakan kegiatan membaca yang menyenangkan dalam lingkungan sekolah. Pembiasaan ini dilakukan untuk menumbuhkan minat baca terhadap bacaan dan geiatan membaca.

b. Tahap ke-2: Pengembangan

Tahap pengembangan dilaksanakan untuk lebih memahami tentang bacaan yang sudah dibaca dan mengaitkannya dengan pengalaman pribadi, melalui kegiatan bacaan pengayaan agar dapat berpikir kritis dan mengolah kemampuan komunikasi secara kreatif.

c. Tahap ke-3: Pelaksaan pembelajaran berbasis literasi 
5090 Pengaruh Budaya Literasi terhadap Hasil Belajar IPA di Sekolah Dasar - Frita Dwi Lestari, Muslimin Ibrahim, Syamsul Ghufron, Pance Mariati

DOI: https://doi.org/10.31004/basicedu.v5i6.1436

Melaksanakan kegiatan pelajaran dengan menerapkan literasi ketika pembelajaran sedang berlangsung (Anggraeni, 2019).

Berdasarkan tahapan di atas, maka dapat dikatakan bahwa penerapan budaya literasi mempunyai tiga tahapan yang harus dilalui. Ketiga tahapan itu adalah tahap pertama pembiasaan yang dilakukan agar siswa terbiasa melakukan kegiatan literasi (membaca) dengan mengajak siswa untuk membaca selama 15 menit sebelum pelajaran dimulai. Tahapan kedua pengembangan yang dilakukan agar siswa lebih memahami tentang apa yang sudah dibaca. Tahapan ketiga, yaitu pelaksanaan pembelajaran berbasis literasi yang bisa dilakukan dengan mengajak meminta salah satu siswa untuk membaca materi pelajaran, kemudian siswa yang lainnya menyimak.

Dalam proses tahapan yang dilakukan dalam penerapan budaya literasi, tentunya aka nada hambatanhambatan yang bisa saja terjadi. Hambatan-hambatan tersebut diantaranya, sebagai berikut:

a. Kegiatan literasi dalam lingkungan keluarga belum menjadi prioritas utama, bahkan terkadang kegiatan membaca harus di mulai dengan paksaan.

b. Minimnya fasilitas untuk membaca, atau kurangnya sumber bacaan.

c. Lingkungan sekitar yang kurang mendukung pelaksanaan budaya literasi.

d. Kurangnya konsentrasi pada anak, sehingga berpengaruh pada tingkat pemahaman pembaca (Aulinda, 2020).

Berdasarkan pemaparan hambatan-hambatan yang bisa saja terjadi saat penerapan budaya literasi di atas, maka dapat disimpulkan bahwa seharusnya budaya literasi juga diterapkan di dalam ligkungan keluarga tidak hanya di sekolah saja. Karena lingkungan eksternal dari sekolah juga mempunyai pengaruh terhadap minat baca pada siswa.

Pada penelitian ini, diharapkan penerapan budaya literasi mampu meningkatkan hasil belajar pada siswa kelas IV. Dimana pengertian hasil belajar itu sendiri, menurut Sudjana (dalam Sulastri et al., 2015) Hasil belajar adalah kemampuan-kemampuan yang telah dimiliki oleh siswa setelah ia mengalami proses belajarnya. Sedangkan menurut Dimyati dan Mudjiono (dalam Sulastri et al., 2015), bahwasanya hasil belajar adalah sesuatu yang dapat dipandang dari dua sisi yakni dari sisi siswa dan dari sisi guru. Hasil belajar dari sisi siswa dapat dilihat pada tingkatan pertumbuhan mental siswa yang lebih baik apabila dibanding pada saat sebelum belajar. Howard Kingsley (dalam Sulastri et al., 2015) membagi 3 berbagai hasil belajar: 1) Kemampuan dan kebiasaan; 2) Pengetahuan dan penafsiran; dan 3) Sikap dan cita-cita. Pendapat dari Horward Kingsley ini merupakan seluruh proses dari belajar yang hendak menujukkan hasil perubahan dari siswa (Sulastri et al., 2015).

Dari beberapa pengertian menurut para ahli di atas maka dapat disimpulkan bahwa hasil belajar adalah suatu penilaian akhir yang di peroleh seseorang dari suatu proses dan pengenalan yang dilakukan secara berulang-ulang. Hasil belajar juga berpengaruh dalam membentuk pribadi individu, karena individu yang ingin mendapatkan hasil belajar yang baik akan mengubah cara berfikir dan perilaku yang baik untuk mendapatkan hasil akhir yang baik pula.

Menurut Nugraha et al., (dalam Anggita et al., 2021) Hasil belajar adalah kemampuan siswa yang diperoleh setelah menyelesaikan latihan-latihan dalam pembelajaran. Perubahan yang terjadi dari diri siswa baik menyangkut aspek kognitif, afektif, dan psikomotor. Perubahan perilaku yang dapat diukur digunakan sebagai bahan pertimbangan bagi siswa dan guru untuk melihat apakah siswa telah lulus atau tidak (Anggita et al., 2021). Menurut Susanto (dalam Saragih et al., 2021) hasil belajar adalah kemampuan yang diperoleh anak setelah melalui kegiatan belajar (Saragih et al., 2021). Sudjana (dalam Sulastri et al., 2015) Hasil belajar adalah kemampuan-kemampuan yang telah dimiliki oleh siswa setelah ia mengalami proses belajarnya (Sulastri et al., 2015).

Dari beberapa pengertian menurut para ahli di atas maka dapat disimpulkan bahwa hasil belajar adalah sebuah kemampuan dari seorang anak yang di dapatkan setelah mendapatkan pelajaran. 
Adapun faktor-faktor yang mempengaruhi hasil belajar pada siswa adalah a.) Minat individu, b.) Motivasi belajar, c.) Kebiasaan membaca. Mualimah dan Umaedi (2018) telah membuktikan kebiasaan membaca berpengaruh pada prestasi. Mualimah dan Umaedi (2018) telah meneliti pengaruh kebiasaan membaca dengan prestasi pelajaran Bahasa Indonesia di SD Kelas V SDN Kubanglaban. Penelitian ini mencoba menjaring kebiasaan membaca siswa dengan angket, kemudian siswa yang berbeda kebiasaan membaca dites untuk melihat prestasinya ternyata siswa yang tingkat kebiasaan membaca $67 \%$ dapat mencapai prestasi 90\%. Di samping itu kebiasaan membaca. Retadiandalas (2017) menemukan bahwa minat baca berhubungan dengan motivasi. Sementara itu telah lama diketahui bahwa motivasi memengaruhi prestasi dengan demikian dapat disimpulkan membaca dapat meningkatkan prestasi siswa (Mualiah \& Usmaedi, 2018).

Berbeda dengan penelitian Mualiah dan Usmaedi (2018), pada penelitian ini penulis ingin memfokuskan pada satu mata pelajaran, yakni pada mata pelajaran IPA. Konsep pembelajaran IPA pada penelitian ini, menempatkan siswa tidak hanya mendengar serta memandang uraian yang diberikan oleh guru, tetapi juga dengan menerapkan budaya literasi ini, guru terlebih dahulu mengajak siswa untuk membaca materi yang akan dipelajari. Setelah membaca siswa dianjurkan untuk menulis kemudian, nantinya akan didiskusikan bersama-sama pada saat proses belajar mengajar. Dalam hal ini siswa sudah ikut serta sejak awal proses belajar mengajar sehingga siswa menjadi subjek bukan objek.

Penerapan budaya literasi yang akan dilakukan oleh peneliti, merupakan upaya untuk melakukan keterlaksanan gerakan literasi sekolah, yang tentunya juga peneliti ingin mengetahui apakah budaya literasi berdampak pada hasil belajar siswa terhadap suatu mata pelajaran yakni IPA dan bagaimana respon guru tentang penerapan budaya literasi ini. Tujuan pembelajaran IPA disekolah dasar memberikan keterampilan untuk melakukan pengamatan (Gingga, 2019).

Berdasarkan latar belakang di atas penulis melaksanakan penelitian dengan mengambil judul "Pengaruh Budaya Literasi Terhadap Hasil Belajar Siswa Kelas IV Pada Mata Pelajaran IPA.”

\section{METODE PENELITIAN}

Jenis dan pendekatan penelitian yang digunakan dalam penelitian ini adalah pendekatan kuantitatif menggunakan rancangan penelitian eksperimen, yaitu rancangan pre eksperimental desin, yaitu PrestestPosttest Control Group Design. Penelitian dilaksanakan pada Tahun Ajaran 2020/2021 bertempat di SDN Wonokusumo VI.

Penelitian ini tidak menerapkan populasi dan sampel karena tidak melakukan sampling dan tidak bertujuan menerapkan hasil penelitian pada populasi. Penelitian hanya menetapkan sasaran penelitian, yaitu siswa kelas IV sejumlah 24 orang yang dipisah menjadi dua kelas, yaitu kelas kontrol dan kelas eksperimen masing-masing dengan 12 orang siswa. Rancangan pre eksperimen pretest-posttest control group design, seperti ditunjukkan pada gambar berikut.

\begin{tabular}{lll}
\hline Pretest & Perlakuan & Posttest \\
\hline $\mathrm{O}_{1}$ & $\mathrm{X}$ & $\mathrm{O}_{2}$ \\
\hline $\mathrm{O}_{3}$ & & $\mathrm{O}_{4}$ \\
\hline
\end{tabular}

Sumber : Notoadmojo, 2010

Di mana:

X : Perlakuan budaya literasi pada kelas eksperimen

$\mathrm{O}_{1} \quad$ : Pretest pada kelas eksperimen

$\mathrm{O}_{2} \quad$ : Posttest pada kelas eksperimen

$\mathrm{O}_{3} \quad$ : Pretest pada kelas kontrol

$\mathrm{O}_{4} \quad$ : Posttest pada kelas kontrol 
5092 Pengaruh Budaya Literasi terhadap Hasil Belajar IPA di Sekolah Dasar - Frita Dwi Lestari, Muslimin Ibrahim, Syamsul Ghufron, Pance Mariati

DOI: https://doi.org/10.31004/basicedu.v5i6.1436

\section{HASIL DAN PEMBAHASAN}

\section{Analisis data Hasi Pengamatan Keterlaksanaan Pembelajaran}

Berdasarkan hasil pengamatan pada kelompok Eksperimen dan Kontrol, Langkah pembelajaran yang dirancang dalam RPP untuk kelompok eksperimen 6 langkah. Banyaknya Langkah yang dilaksanakan dengan skor minimal 3 = 6 Langkah dengan demikian Langkah-langkah pembelajaran yang dirancang di dalam RPP telah dilaksanakan 100\%. Berarti Pembelajaran kelompok eksperimen telah terlaksana.

Tabel 1 Keterlaksanaan Pembelajaran Kelas Eksperimen

\begin{tabular}{|c|c|c|c|c|c|c|c|}
\hline \multirow[t]{2}{*}{ No. } & \multirow{2}{*}{$\begin{array}{l}\text { Langkah Pokok Pembelajaran yang } \\
\text { diamati }\end{array}$} & \multicolumn{2}{|c|}{ Dilakukan } & \multicolumn{4}{|c|}{$\begin{array}{l}\text { Skor } \\
\text { kualitas }\end{array}$} \\
\hline & & $\mathbf{Y a}$ & Tidak & 4 & 3 & 2 & $\mathbf{1}$ \\
\hline 1. & Membagi link untuk akses flipbook & $\sqrt{ }$ & & & $\sqrt{ }$ & & \\
\hline 2. & $\begin{array}{l}\text { Melakukan pembudayaan literasi dengan } \\
\text { membimbing siswa membaca selama } 15 \\
\text { menit sebelum } \quad \text { pembelajaran } \\
\text { (kel.eksperimen saja) }\end{array}$ & $\sqrt{ }$ & & & $\sqrt{ }$ & & \\
\hline 3. & $\begin{array}{l}\text { Pembelajaran rutin sesuai dengan RPP Guru } \\
\text { (Kedua kelas) }\end{array}$ & $\sqrt{ }$ & & & $\sqrt{ }$ & & \\
\hline 4. & $\begin{array}{l}\text { Tahap pemdahuluan memberi salam, } \\
\text { memotivasi siswa, melakukan apersepsi dan } \\
\text { menyampaikan tujuan }\end{array}$ & $\sqrt{ }$ & & & $\sqrt{ }$ & & \\
\hline 5. & $\begin{array}{l}\text { Kegiatan ini mengelaborasi kegiatan } \\
\text { pembelajaran melalui berbagai strategi } \\
\text { ceramah, penugasan, mengamati, membaca } \\
\text { menyimpulkan pembelajaran pada akhir } \\
\text { kegitan ini }\end{array}$ & $\sqrt{ }$ & & & $\sqrt{ }$ & & \\
\hline 6. & $\begin{array}{l}\text { Kegiatan penutup dilakukan misalnya } \\
\text { membuat rangkuman, melakukan evaluasi, } \\
\text { atau mencari bentuk-bentuk penerapan }\end{array}$ & $\sqrt{ }$ & & & $\sqrt{ }$ & & \\
\hline
\end{tabular}

\section{Banyaknya langkah yang terlaksana (skor minimal 3) $x 100 \%$}

Banyaknya langkah total

$$
\begin{aligned}
& =\frac{6}{6} \times 100 \% \\
& =100 \%
\end{aligned}
$$

Tabel di atas menunjukkan bahwa presentase langkah-langkah guru dalam mengajar dengan menerapkan budaya literasi pada mata pelajaran IPA untuk kelas eksperimen telah $100 \%$ terlaksana. Tabel diatas mencakup seluruh indikator pembelajaran yang dirancang sesuai RPP dan dilaksanakan oleh guru.

\begin{tabular}{|c|c|c|c|c|c|c|c|}
\hline \multirow[t]{2}{*}{ No. } & \multirow[t]{2}{*}{ Pembelajaran yang } & \multicolumn{2}{|c|}{ Dilakukan } & \multicolumn{4}{|c|}{$\begin{array}{l}\text { Skor } \\
\text { kualitas }\end{array}$} \\
\hline & & Ya & Tidak & 4 & 3 & 2 & 1 \\
\hline 1. & Membagi link untuk akses flipbook & & & & & & \\
\hline 2. & $\begin{array}{l}\text { Melakukan pembudayaan literasi dengan } \\
\text { membimbing siswa membaca selama } 15 \\
\text { menit sebelum } \\
\text { (kel.eksperimen saja) }\end{array}$ & & & & & & \\
\hline 3. & $\begin{array}{l}\text { Pembelajaran rutin sesuai dengan RPP Guru } \\
\text { kelas kontrol }\end{array}$ & $\sqrt{ }$ & & & $\sqrt{ }$ & & \\
\hline
\end{tabular}

Tabel 2 Keterlaksanaan Pembelajaran Kelas Kontrol 


\begin{tabular}{|c|c|c|c|c|c|c|}
\hline \multirow[t]{2}{*}{ No. } & \multirow{2}{*}{$\begin{array}{l}\text { Langkah Pokok Pembelajaran yang } \\
\text { diamati }\end{array}$} & \multicolumn{2}{|c|}{ Dilakukan } & \multicolumn{3}{|c|}{$\begin{array}{l}\text { Skor } \\
\text { kualitas }\end{array}$} \\
\hline & & Ya & Tidak & 4 & 32 & 1 \\
\hline 4. & $\begin{array}{l}\text { Tahap pemdahuluan memberi salam, } \\
\text { memotivasi siswa, melakukan apersepsi dan } \\
\text { menyampaikan tujuan }\end{array}$ & $\sqrt{ }$ & & & $\sqrt{ }$ & \\
\hline 5. & $\begin{array}{l}\text { Kegiatan ini mengelaborasi kegiatan } \\
\text { pembelajaran melalui berbagai strategi } \\
\text { ceramah, penugasan, mengamati, membaca } \\
\text { menyimpulkan pembelajaran pada akhir } \\
\text { kegitan ini }\end{array}$ & $\sqrt{ }$ & & & $\sqrt{ }$ & \\
\hline 6. & $\begin{array}{l}\text { Kegiatan penutup dilakukan misalnya } \\
\text { membuat rangkuman, melakukan evaluasi, } \\
\text { atau mencari bentuk-bentuk penerapan }\end{array}$ & $\sqrt{ }$ & & & $\sqrt{ }$ & \\
\hline
\end{tabular}

\section{Banyaknya langkah yang terlaksana (skor minimal 3) $\times 100 \%$}

Banyaknya langkah total

$$
\begin{aligned}
& =\frac{4}{4} \times 100 \% \\
& =100 \%
\end{aligned}
$$

Tabel di atas menunjukkan bahwa presentase langkah-langkah guru dalam mengajar pembelajaran konvensional untuk kelas kontrol telah $100 \%$ terlaksana. Tabel di atas mencakup seluruh indikator pembelajaran yang di rancang sesuai RPP dan dilaksanakan oleh guru.

Selain pengamatan kerlaksanaan pembelajaran juga diamati aktivitas peseta didik untuk memerkuat bukti keterlaksanaan pembelajaran. Hasil Pengamatan Terhadap peserta didik disajikan pada Tabel 3 berikut.

\begin{tabular}{|c|c|c|c|c|c|c|c|c|c|c|c|c|c|}
\hline \multirow{2}{*}{ No. } & \multirow{2}{*}{ Pernyataan } & \multicolumn{12}{|c|}{ Siswa yang diamati } \\
\hline & & 1 & 2 & 3 & 4 & 5 & 6 & 7 & 8 & 9 & 10 & 11 & 12 \\
\hline 1. & $\begin{array}{l}\text { Peserta didik tepat waktu mengikuti } \\
\text { kegiatan belajar mengajar. }\end{array}$ & $\sqrt{ }$ & $\sqrt{ }$ & $\sqrt{ }$ & $\sqrt{ }$ & $\sqrt{ }$ & $\sqrt{ }$ & $\sqrt{ }$ & $\sqrt{ }$ & $\sqrt{ }$ & $\sqrt{ }$ & $\sqrt{ }$ & $\sqrt{ }$ \\
\hline 2. & $\begin{array}{l}\text { Pendidik menjelaskan materi } \\
\text { pembelajaran, peserta didik dapat } \\
\text { mengikuti dengan baik. }\end{array}$ & $\sqrt{ }$ & $\sqrt{ }$ & $\sqrt{ }$ & $\sqrt{ }$ & $\sqrt{ }$ & $\sqrt{ }$ & $\sqrt{ }$ & $\sqrt{ }$ & $\sqrt{ }$ & $\sqrt{ }$ & $\sqrt{ }$ & $\sqrt{ }$ \\
\hline 3. & $\begin{array}{l}\text { Peserta didik menunjukkan sikap aktif } \\
\text { ketika mengikuti proses pembelajaran } \\
\text { IPA. }\end{array}$ & $\sqrt{ }$ & $\sqrt{ }$ & $\sqrt{ }$ & $\sqrt{ }$ & $\sqrt{ }$ & $\sqrt{ }$ & $\sqrt{ }$ & $\sqrt{ }$ & $\sqrt{ }$ & $\sqrt{ }$ & $\sqrt{ }$ & $\sqrt{ }$ \\
\hline 4. & $\begin{array}{l}\text { Peserta didik dapat mengerjakan soal } \\
\text { pretest secara bersungguh-sungguh. }\end{array}$ & $\sqrt{ }$ & $\sqrt{ }$ & $\sqrt{ }$ & $\sqrt{ }$ & $\sqrt{ }$ & $\sqrt{ }$ & $\sqrt{ }$ & $\sqrt{ }$ & $\sqrt{ }$ & $\sqrt{ }$ & $\sqrt{ }$ & $\sqrt{ }$ \\
\hline 5. & $\begin{array}{l}\text { Peserta membaca materi pelajaran IPA } \\
\text { dengan tenang. }\end{array}$ & $\sqrt{ }$ & $\sqrt{ }$ & $\sqrt{ }$ & $\sqrt{ }$ & $\sqrt{ }$ & $\sqrt{ }$ & $\sqrt{ }$ & $\sqrt{ }$ & $\sqrt{ }$ & $\sqrt{ }$ & $\sqrt{ }$ & $\sqrt{ }$ \\
\hline 6. & $\begin{array}{l}\text { Peserta didik selalu semangat dan } \\
\text { antusias saat mengerjakan soal post test. }\end{array}$ & $\sqrt{ }$ & $\sqrt{ }$ & $\sqrt{ }$ & $\sqrt{ }$ & $\sqrt{ }$ & $\sqrt{ }$ & $\sqrt{ }$ & $\sqrt{ }$ & $\sqrt{ }$ & $\sqrt{ }$ & $\sqrt{ }$ & $\sqrt{ }$ \\
\hline
\end{tabular}

Tabel 3 Hasil Pengamatan Aktivitas Siswa 
5094 Pengaruh Budaya Literasi terhadap Hasil Belajar IPA di Sekolah Dasar - Frita Dwi Lestari, Muslimin Ibrahim, Syamsul Ghufron, Pance Mariati

DOI: https://doi.org/10.31004/basicedu.v5i6.1436

\section{Analisis Data Hasil Belajar}

Hasil uji normalitas data diperoleh data berdistribusi normal. Karena $\mathrm{L}_{\text {hitung }}=0,75$ dan $\mathrm{L}_{\text {tabel }}$ pada taraf signifikansi alpha $0,05=0,242$ pada hasil nilai pretest kelas eksperimen, dan $\mathrm{L}_{\text {hitung }}=0,10$ dan $\mathrm{L}_{\text {tabel }}$ pada taraf signifikansi alpha $0,05=0,242$ pada hasil nilai posttest kelas eksperimen. Kemudian, $\mathrm{L}_{\text {hitung }}=0,16$ dan $\mathrm{L}_{\text {tabel }}$ pada taraf signifikansi alpha $0,05=0,242$ pada hasil nilai pretest kelas kontrol dan $\mathrm{L}_{\text {hitung }}=0,26$ dan $\mathrm{L}_{\text {tabel }}$ pada taraf signifikansi alpha $0,05=0,242$ pada hasil nilai posttest kelas kontrol.

Dengan demikian $\mathrm{L}_{\text {hitung }}<\mathrm{L}_{\text {tabel. }}$. Hasil Penghitungan Homogenitas diperoleh hasil data berdistribusi homogen karena $F_{\text {hiutng }}=1,08$ dan $F_{\text {tabel }}=2,82$ pada hasil nilai pretest kelas eksperimen dan kontrol. Kemudian, $F_{\text {hiutng }}=0,08$ dan $F_{\text {tabel }}=2,82$ pada hasil nilai posttest kelas eksperimen dan kontrol, sehingga dengan demikian $\mathrm{F}_{\text {hiutng }}<\mathrm{F}_{\text {tabel }}$ bermakna data homogen.

Karena asumsi normalitas dan homogenitas terpenuhi, maka uji perbedaan menggunakan statistik parametrik uji $\mathrm{t}$ dengan data homogen sampel tidak berpasangan, yang dilakukan melakukan uji perbedaan rerata peningkatan dari pretest ke posttest.

$$
t=\frac{\bar{X}_{1}-\bar{X}_{2}}{\sqrt[S]{\frac{1}{n_{1}}+\frac{1}{n_{2}}}} \quad S=\sqrt{\frac{\left(n_{1}-1\right) S_{1}{ }^{2}+\left(n_{2}-1\right) S_{2}{ }^{2}}{\left(n_{1}+n_{2}\right)-2}}
$$

Tabel 4 Kerja Uji T

\begin{tabular}{|c|c|c|c|}
\hline \multirow[t]{2}{*}{ No. } & \multicolumn{2}{|c|}{ Selisih Post dan Pretest } & \\
\hline & $\begin{array}{ll}\mathrm{K} & \text { Eksperimen } \\
\left(\mathrm{X}_{1}\right) & \end{array}$ & K Kontrol $\left(\mathrm{X}_{2}\right)$ & \\
\hline 1. & $86-66=20$ & $78-60=18$ & $\begin{array}{l}\bar{X}_{1}: \text { Rata-rata kelas eksperimen } \\
\bar{X}_{2}: \text { Rata-rata kelas kontrol }\end{array}$ \\
\hline 2. & $84-76=8$ & $80-70=10$ & $\begin{array}{l}S: \text { Variansi gabungan } \\
n_{1}: \text { Jumlah data kelas eksper }\end{array}$ \\
\hline 3. & $80-72=8$ & $78-70=8$ & $n_{2}:$ Jumlah data kelas kontrol \\
\hline 4. & $90-76=14$ & $80-72=8$ & $S_{1}^{2}:$ Harga varian kelas eksp. \\
\hline 5. & $90-80=10$ & $80-78=2$ & $S_{2}{ }^{2}:$ Harga varian kelas control \\
\hline 6. & $88-70=18$ & $78-66=12$ & \\
\hline 7. & $92-74=18$ & $78-72=6$ & \\
\hline 8. & $92-74=18$ & $80-70=10$ & \\
\hline 9. & $94-70=24$ & $78-66=12$ & \\
\hline 10. & $84-78=6$ & $82-76=6$ & \\
\hline 11. & $86-76=10$ & $80-72=8$ & \\
\hline 12. & $90-80=10$ & $82-78=4$ & \\
\hline
\end{tabular}


5095 Pengaruh Budaya Literasi terhadap Hasil Belajar IPA di Sekolah Dasar - Frita Dwi Lestari, Muslimin Ibrahim, Syamsul Ghufron, Pance Mariati

DOI: https://doi.org/10.31004/basicedu.v5i6.1436

\begin{tabular}{lll}
\hline No. & \multicolumn{3}{l}{ Selisih Post dan Pretest } \\
\cline { 2 - 3 } & $\begin{array}{l}\mathrm{K} \\
\left(\mathrm{X}_{1}\right)\end{array}$ & Eksperimen \\
& $\mathrm{K}$ Kontrol $\left(\mathrm{X}_{2}\right)$ \\
\hline Rerata & 13,6 & 8,6 \\
\hline
\end{tabular}

Berdasarkan data pada tabel tersebut diperoleh

$\mathrm{T}_{\text {hitung }}=2,426$

$\mathrm{T}_{\text {tabel }}=2,179$

Dengan demikian berarti hipotesis null Ho di tolak dan Ha di terima

\section{Analisis Data Respon Guru}

Data respon guru dianalisis menggunakan Teknik deskriptif, bentuk-bentuk respon di daftar dan dipilih berdasarkan repon positif dan atau negatif.

\begin{tabular}{|c|}
\hline \multirow[b]{2}{*}{$\begin{array}{l}\text { Respon Positif } \\
\text { Menurut bu Aminingsih selaku } \\
\text { narasumber dalam wawancara ini, } \\
\text { budaya literasi efektif untuk dilaksakan } \\
\text { dalam pembelajaran. }\end{array}$} \\
\hline \\
\hline $\begin{array}{l}\text { Penerapan budaya literasi } \\
\text { membangkitkan antusias siswa untuk } \\
\text { membaca atau membangkitkan } \\
\text { motivasi siswa untuk membaca. }\end{array}$ \\
\hline $\begin{array}{l}\text { Budaya literasi berpengaruh terhadap } \\
\text { hasil belajar siswa, karena dengan } \\
\text { banyak membaca siswa mendapat } \\
\text { banyak wawasan dan bisa memahami } \\
\text { materi pelajaran. }\end{array}$ \\
\hline
\end{tabular}

Dari tabel respon guru, dapat disimpulkan bahwa mendukung adanya penerapan budaya literasi pada pembelajaran. Bu Aminingsih selaku wali kelas IV juga menyatakan, bahwa nantinya tentu saja akan ada pengaruh terhadap hasil belajar siswa yang suka membaca dan yang tidak. Selain itu, budaya literasi juga bisa membangkitkan motivasi siswa untuk membaca.

Berdasarkan hasil analisis data, hasil penelitian berupa keterlaksanaan pembelajaran, hasil belajar siswa (pretest dan posttest), dan hasil wawancara. Pada lembar keterlaksanaan pembelajaran mulai dari kegiatan awal, kegiatan inti, dan kegiatan penutup diperoleh skor 100\%, yang mana pembelajaran dengan menerapkan budaya literasi pada kelas eksperimen dan pembelajaran konvensional pada kelas kontrol dapat dkatakan terlaksana.

Kemudian, dalam pengambilan data pretest siswa kelas eksperimen diberikan sedikit ulasan kembali materi tentang bunyi oleh guru, kemudian siswa diminta mengerjakan lembar soal pretest tanpa menggunakan media flipbook sebagai treatment budaya literasi. Pengambilan data posttest kelas eksperimen menggunakan lembar soal posttest siswa dengan menggunakan media flipbook sebagai bahan bacaan (literasi) sebelum pengerjaan posttest.

Dalam pengambilan data pretest pada kelas kontrol diberikan sedikit ulasan kembali tentang materi bunyi, kemudian siswa diminta mengerjakan lembar soal pretest tanpa menggunakan media flipbook sebagai 
treatment. Pengambilan data posttest pada kelas kontrol dilakukan dengan guru menjelaskan materi bunyi dengan metode ceramah atau kovensional, namun siswa tidak diberikan treatment berupa bahan bacaan (literasi) kemudian, siswa diminta mengerjakan lembar soal posttest.

Hasil pretest menunjukkan bahwa masih ada siswa yang tidak mencapai nilai KKM baik dari kelas eksperimen maupun kelas kontrol. Hal tersebut bisa terjadi karena siswa hanya di beri sedikit ulasan tentang materi yang ada dalam lembar soal pretest. Dimana siswa kurang bisa memperhatikan penjelasan yang di berikan oleh guru.

Selanjutnya dilakukan uji posttest dengan menggunakan penerapan budaya literasi pada kelas eksperimen. Dikarenakan adanya covid-19, dalam hal ini untuk pengambilan data peneliti menggunakan media flipbook sebagai bahan bacaan (literasi) yang dikirimkan melalui whatsapp berupa link. Setelah diberikan bahan bacaan dan penjelasan kembali oleh peneliti, maka diperoleh hasil posttest yang meningkat dan dapat dinyatakan bahwa ada pengaruh saat siswa di berikan treatment berupa literasi (membaca). Siswa menjadi lebih aktif dalam pembelajaran karena sedikit banyak sudah membaca materi yang akan di pelajari.

Untuk uji posttest pada kelas kontrol, peneliti hanya menjelaskan materi dengan metode ceramah atau pembelajaran konvensional. Kemudian, siswa kelas kontrol diminta untuk menyelesaikan lembar soal posttest. Pada hasil posstest kelas kontrol juga meningkat, namun ada perbedaan nilai dengan kelas eksperimen. Dimana untuk hasil belajar kelas eksperimen lebih tinggi dibandingkan kelas kontrol. Hal tersebut terjadi karena kelas eksperimen mendapatkan treatmen berupa budaya literasi.

Hasil pretest dengan bantuan program perhitungan Microsoft Excel 2016 dengan metode liliefors, maka diperoleh nilai $\mathrm{L}_{\text {hitung }}=0,75$ dan $\mathrm{L}_{\text {tabel }}=0,242$ pada hasil pretest kelas eksperimen. Nilai $\mathrm{L}_{\text {hitung }}=0,10$ dan $\mathrm{L}_{\text {tabel }}$ $=0,242$ diperoleh dari nilai posttest kelas eksperimen. Kemudian, hasil nilai pretest pada kelas kontrol diperoleh $\mathrm{L}_{\text {hitung }}=0,16$ dan $\mathrm{L}_{\text {tabel }}=0,242$. Untuk hasil nilai posttest pada kelas kontrol diperoleh nilai $\mathrm{L}_{\text {hitung }}=$ 0,26 dan $\mathrm{L}_{\text {tabel }}=0,242$ dengan demikian dapat dismpulkan, bahwa semua data berdistribusi normal karena dari semua data yang diporeh menunjukkan bahwa $\mathrm{L}_{\text {hitung }}<\mathrm{L}_{\text {tabel. }}$.

Setelah dilakukan uji normalitas dengan metode liliefors, selanjutnya semua data akan di uji homogenitas dengan uji F melalui Microsoft Excel 2016 untuk mengetahui apakah semua data tersebut homogen atau tidak. Maka nilai $F_{\text {hitung }}=1,08$ dan $F_{\text {tabel }}=2,92$ pada hasil nilai pretest dan posttes kelas eksperimen. Nilai $\mathrm{F}_{\text {hitung }}=0,08$ dan $\mathrm{F}_{\text {tabel }}=2,82$ pada hasil nilai pretest dan posttest kelas kontrol. Dilihat dari hasil nilai $F_{\text {hitung }}$ dan $F_{\text {tabel }}$ kedua data tersebut dapat dinyatakan bahwa, $F_{\text {hitung }}<F_{\text {tabel }}$ yang artinya semua data homogen.

Untuk mengetahui apakah penerepan budaya literasi di kelas IV pada mata pelajaran IPA berpengaruh pada hasil belajar siswa, maka dilakukan uji hipotesis dengan melakukan uji perbedaan menggunakan statistic parametrik uji t dengan data homogen sampel tidak berpasangan, yang dilakukan melakukan uji perbedaan rerata peningkatan dari pretest ke posttest. Dimana dari hasil perhitungan tersebut diperoleh nilai $t_{\text {hitung }}=2,426$ dan $t_{\text {tabel }}=2,075$ hal tersebut dapat dinyatakan bahwa, $t_{\text {hitung }}>t_{\text {tabel }}$ yang artinya Ho ditolak dan Ha diterima. Jika Ho ditolak dan Ha diterima dapat dinyatakan bahwa, penerepan budaya literasi mempunyai pengaruh yang signifikan terhadap hasil belajar siswa kelas IV pada mata pelajaran IPA.

Semua data dari hasil belajar di ambil ketika pembelajaran sudah terlaksana sesuai dengan RPP yang sudah terlampir. Dimana kelas eksperimen diberikan treatment budaya literasi, dan kelas kontrol hanya melakukan pembelajaran konvensional. Sistem pembelajaran pada penelitian ini $100 \%$ terlaksana sesuai dengan RPP yang terlampir.

Dari semua analisis data yang sudah dilakukan oleh peneliti, dapat disimpulkan bahwa budaya literasi memiliki pengaruh terhadap hasil belajar siswa kelas IV pada mata Pelajaran IPA. Hal tersebut, juga di katakan oleh guru yang di wawancara. Beliau mengatakan tentu ada pengaruh pada hasil belajar siswa yang suka membaca dengan yang tidak. Selain itu, budaya literasi ini efektif dilaksanakan untuk membantu siswa meningkatkan minat baca dan hasil belajarnya. 
5097 Pengaruh Budaya Literasi terhadap Hasil Belajar IPA di Sekolah Dasar - Frita Dwi Lestari, Muslimin Ibrahim, Syamsul Ghufron, Pance Mariati

DOI: https://doi.org/10.31004/basicedu.v5i6.1436

Menurut Alberta (dalam Azizah et al., 2018) dimana ketika seseorang banyak membaca dan menulis, akan mendapatkan pengetahuan, selain itu juga dapat mengasah keterampilan, berfikir kritis terhadap masalah yang ada (Azizah et al., 2018).

Dari pengertian literasi yang dipaparkan oleh Alberta, dapat disimpulkan bahwa literasi memberikan pengaruh terhadap wawasan atau pengetahuan seseorang yang tentunya akan membuat seseorang dapat berfikir secara kritis. Sehingga ketika budaya literasi diterapkan di dalam sebuah kelas maka, siswa yang ada di dalam kelas tersebut akan mempunyai banyak wawasan yang tentunya membuat siswa berfikir kritis terhadap pembelajaran yang dilaksanakan yang tentunya akan mempengaruhi hasil belajar yang akan diperoleh siswa.

\section{KESIMPULAN}

Berdasarkan hasil penelitian dan pembahasan yang sudah dipaparkan diatas tentang "Pengaruh Budaya Literasi Terhadap Hasil Belajar Siswa Kelas IV Pada Mata Pelajaran IPA" dapat disimpulkan bahwa keterlaksanaan pembelajaran, hasil belajar siswa (pretest dan posttest), dan hasil wawancara. Pada lembar keterlaksanaan pembelajaran mulai dari kegiatan awal, kegiatan inti, dan kegiatan penutup diperoleh skor $100 \%$, yang mana pembelajaran dengan menerapkan budaya literasi pada kelas eksperimen dan pembelajaran konvensional pada kelas kontrol dapat dkatakan terlaksana.

Selanjutnya, hasil belajar siswa yang diperoleh dari pretest dan posttest dilakukan uji normalitas, uji homogenitas, dan uji hipotesis untuk dianalisis adanya pengaruh penerapan budaya literasi pada hasil belajar siswa pada mata pelajaran IPA atau tidak. Pada uji normalitas yang menggunakan metode liliefors tedapat perbedaan antara hasil pretest kelas eksperimen dan pretest kelas kontrol, dengan nilai mean pretest kelas kontrol lebih kecil dari nilai mean pretest kelas eksperimen $(74,33>70,83)$. Sedangkan untuk nilai mean kelas eksperimen lebih besar daripada nilai posttest kelas kontrol $(88,00>79,50)$. Perbedaan nilai mean pada kelas eksperimen dan kontrol membuktikan nahwa treatmen berupa budaya literasi (membaca) mempunyai pengaruh pada hasil belajar siswa kelas IV pada mata pelajaran IPA.

Setelah itu, dilakukan uji homogenitas untuk mengetahui data berdistibusi normal atau tidak. Hasil penghitungan Homogenitas diperoleh hasil data berdistribusi normal karena $F_{\text {hiutng }}=1,08$ dan $F_{\text {tabel }}=2,82$ pada hasil nilai pretest kelas eksperimen dan kontrol. Kemudian, $F_{\text {hiutng }}=0,08$ dan $F_{\text {tabel }}=2,82$ pada hasil nilai posttest kelas eksperimen dan kontrol, sehingga dengan demikian $\mathrm{F}_{\text {hiutng }}<\mathrm{F}_{\text {tabel }}$ bermakna data homogen.

Karena asumsi normalitas dan homogenitas terpenuhi, maka uji perbedaan menggunakan statistik parametrik uji t dengan data homogen sampel tidak berpasangan, yang dilakukan melakukan uji perbedaan rerata peningkatan dari pretest ke posttest. Hasil dari perhitungan uji $t$ diperoleh nilai $t_{\text {hitung }}=2,426$ dan $t_{\text {tabel }}=2,075$ hal tersebut dapat dinyatakan bahwa, $t_{\text {hitung }}>t_{\text {tabel }}$ yang artinya Ho ditolak dan Ha diterima. Jika Ho ditolak dan Ha diterima dapat dinyatakan bahwa, penerepan budaya literasi mempunyai pengaruh yang signifikan terhadap hasil belajar siswa kelas IV pada mata pelajaran IPA.

Pada hasil wawancara yang dilakukan oleh peneliti dengan Ibu Aminingsih selaku wali kelas IV, peneliti mendapatkan respon positif dari guru dalam melakukan penerapan budaya literasi dalam pembelajaran. Beliau juga mengatakan bahwa tentu ada pengaruh pada hasil belajar siswa yang suka membaca dengan yang tidak. Selain itu, budaya literasi ini efektif dilaksanakan untuk membantu siswa meningkatkan minat baca dan hasil belajarnya.

\section{DAFTAR PUSTAKA}

Amiyah, F., \& Subiyantoro, H. (2020). Membangun Budaya Religius Siswa Melalui Kegiatan Sekolah Lignkungan Sma Sunan Ampel. 17(2). 
5098 Pengaruh Budaya Literasi terhadap Hasil Belajar IPA di Sekolah Dasar - Frita Dwi Lestari, Muslimin Ibrahim, Syamsul Ghufron, Pance Mariati

DOI: https://doi.org/10.31004/basicedu.v5i6.1436

Anggita, R., 1, T., Sumarni, W., \& Utomo, U. (2021). Pengaruh Pembelajaran Daring Dan Motivasi Belajar Terhadap Hasil Belajar Siswa Di Sekolah Dasar. Jurnal Basicedu, 5(5), 3125-3133. Https://Doi.Org/10.31004/Basicedu.V5i5.1291

Anggraeni, P. R. (2019). Implementasi Kebijakan Literasi Sekolah Guna Peningkatan Karakter Gemar Membaca. Indonesian Journal Of Sociology, Education, And Development, 1(2), 132-142. Https://Doi.Org/10.52483/Ijsed.V1i2.12

Aswat, H., \& Nurmaya G, A. L. (2019). Analisis Gerakan Literasi Pojok Baca Kelas Terhadap Eksistensi Dayabaca Anak Di Sekolah Dasar. Jurnal Basicedu, 4(1), 70-78. Https://Doi.Org/10.31004/Basicedu.V4i1.302

Aulinda, I. F. (2020). Menanamkan Budaya Literasi Pada Anak Usia Dini Di Era Digital. Abdau: Jurnal Pendidikan Madrasah Ibtidaiyah, 6(2), 148-172. Https://Doi.Org/10.36768/Abdau.V2i1.41

Azizah, A. L., Latief, A. M., \& Tumanggung, A. (2018). Efektivitas Kepemimpinan Kepala Sekolah Dalam Mengembangkan Budaya Literasi. Iq (Ilmu Al-Qur'an): Jurnal Pendidikan Islam, 1(02), 199-219. Https://Doi.Org/10.37542/Iq.V1i02.16

Chairunnisa, C. (2018). Pengaruh Literasi Membaca Dengan Pemahaman Bacaan (Penelitian Survei Pada Mahasiswa Stkip Kusumanegara Jakarta). Jurnal Tuturan, 6(1), 745. Https://Doi.Org/10.33603/Jt.V6i1.1584

Dafit, F., Mustika, D., \& Melihayatri, N. (2020). Pengaruh Program Pojok Literasi Terhadap Minat Baca Mahasiswa. Jurnal Basicedu, 4(1), 117-130. Https://Doi.Org/10.31004/Basicedu.V4i1.307

Devianty, R. (2017). Bahasa Sebagai Cermin Kebudayaan. Jurnal Tarbiyah, 24(2), 226-245.

Gingga. (2019). Korelasi Antara Motivasi Belajar Dengan Hasil Belajar Siswa Dalam Pembelajaran Ipa Di Sekolah Dasar. Jurnal Basicedu, 3(3), 909-915.

Gogahu, D. G. S., \& Prasetyo, T. (2020). Pengembangan Media Pembelajaran Berbasis E-Bookstory Untuk Meningkatkan Literasi Membaca Siswa Sekolah Dasar. Jurnal Basicedu, 4(4), 1004-1015. Https://Doi.Org/10.31004/Basicedu.V4i4.493

Kamardana, G., Lasmawan, I. ., \& Suarni, N. . (2021). Efektivitas Gerakan Literasi Sekolah Terhadap Minat Baca Dan Hasil Belajar Di Kelas V Sd Gugus Ii Tejakula Tahun Pelajaran 2019/2020. Pendasi: Jurnal Pendidikan Dasar Indonesia, X(X), 115-125. Https://Repo.Undiksha.Ac.Id/4391/

Lawalata, A. K., \& Sholeh, M. (2019). Pengaruh Program Literasi Terhadap Minat Baca Dan Prestasi Belajar Siswa Di Smp Islam Al-Azhaar Tulungagung. Inspirasi Manajemen Pendidikan, 7(3), 1-12. Https://Jurnalmahasiswa.Unesa.Ac.Id/Index.Php/Inspirasi-ManajemenPendidikan/Article/Viewfile/28880/26445

Mualiah, E. N., \& Usmaedi. (2018). Pengaruh Kebiasaan Membaca Terhadap Prestasi Belajar Bahasa Indonesia Siswa Kelas V Sdn Kubanglaban. Jurnal Untirta, 4(1), 43-55.

Purwati, S. (2017). Program Literasi Membaca 15 Menit Sebelum Pelajaran Dimulai Untuk Mningkatkan Hasil Belajar Membaca Dan Menghafal Surah Pendek. Jurnal Ilmu Pendidikan Sosial, Sains, Dan Humaniora, 3(4), 663-670.

Safitri, V., \& Dafit, F. (2021). Peran Guru Dalam Pembelajaran Membaca Dan Menulis Melalui Gerakan Literasi Di Sekolah Dasar. Jurnal Basicedu, 5(3), 1356-1364. Https://Jbasic.Org/Index.Php/Basicedu/Article/View/938

Saragih, L. M., Tanjung, D. S., \& Anzelina, D. (2021). Pengaruh Model Pembelajaran Open Ended Terhadap Hasil Belajar Siswa Pada Pembelajaran Tematik. Jurnal Basicedu, 5(4), 2156-2163.

Subakti, H., Oktaviani, S., \& Angraini, K. (2021). Implementasi Gerakan Literasi Sekolah Pada Masa Pandemi Covid-19 Dalam Meningkatkan Minat Baca Siswa Sekolah Dasar. Jurnal Basicedu, 5(4), 2156-2163. 
5099 Pengaruh Budaya Literasi terhadap Hasil Belajar IPA di Sekolah Dasar - Frita Dwi Lestari, Muslimin Ibrahim, Syamsul Ghufron, Pance Mariati

DOI: https://doi.org/10.31004/basicedu.v5i6.1436

Sulastri, Imran, \& Firmansyah, A. (2015). Meningkatkan Hasil Belajar Siswa Melalui Strategi Pembelajaran Berbasis Masalah Pada Mata Pelajaran Ips Di Kelas V Sdn 2 Limbo Makmur Kecamatan Bumi Raya. Jurnal Kreatif Tadulako Online, 3(1), 90-103.

Widiyono, S., \& Nurhayati, A. S. (N.D.). Mendidik Anak Dengan Literasi Menuju Pendidikan Yang Berkualitas. 15. 